\title{
DETERMINATION OF APPROPRIATE TECHNIQUE ON CRYSTALLIZATION AND FRACTIONATION OF COCONUT OIL
}

\author{
[Penentuan Teknik Kristalisasi dan Fraksinasi yang Sesuai untuk Minyak Kelapa]
}

\author{
Mursalin $^{1,3) \star}$, Purwiyatno Hariyadi ${ }^{2,3)}$, Eko Hari Purnomo ${ }^{2,3)}$, \\ Nuri Andarwulan ${ }^{2,3)}$, and Dedi Fardiaz ${ }^{2,3)}$ \\ 1) Faculty of Agriculture Technology, Jambi University, Jambi \\ 2) Department of Food Science and Technology, Faculty of Agriculture Technology, Bogor Agricultural University, Bogor \\ ${ }^{3)}$ Southeast Asia Food and Agriculture Science and Technology Center, Bogor Agricultural University, Bogor
}

Approved March $12^{\text {th }} 2016 /$ Accepted November $11^{\text {th }} 2016$

\begin{abstract}
Each kind of oil has different characteristics and physico-chemical properties. Therefore, cooling method applied during dry fractionation of oil must be specifically designed. Fractionation condition of coconut oil commonly uses the fractionation data of palm oil, soybean oil, butter milk, and other commercial oil. Therefore, a more suitable cooling method for coconut oil needs to be investigated. The study showed that there were three distinct cooling phases critical to crystallization process, i.e. initial cooling, critical cooling and crystallization phase. The initial cooling phase is a process of lowering the rejuvenated oil temperature to the temperature for the onset of oil crystallization. For coconut oil, the onset of crystallization temperature was found at $29^{\circ} \mathrm{C}$. The critical cooling phase is cooling from $29^{\circ} \mathrm{C}$ to the crystallization temperature. Crystallization phase is a phase to maintain the oil temperature constant at a predetermined crystallization temperature. In the initial cooling phase, melted coconut oil might be cooled quickly to save time but in the critical cooling phase, it should be done with a cooling rate of less than $0.176^{\circ} \mathrm{C} / \mathrm{min}$ to produce a physically stable crystal. This study has successfully formulated a typical dry fractionation for coconut oil at pilot plant scale $(120 \mathrm{~kg})$ and resulted in an effective cooling procedure to produce oil fractions with physico-chemical properties as expected. The conditions and essential requirements that must be managed and maintained in a dry fractionation stage of coconut oil had been identified and were known. Hence, the fractionation process for specific purposes can be designed in a more practical way.
\end{abstract}

Keywords: coconut oil, cooling rate, crystallization, fractionation

\begin{abstract}
ABSTRAK
Setiap minyak memiliki karakteristik dan sifat fisiko-kimia yang berbeda, oleh karena itu metode pendinginan yang diterapkan saat fraksinasi harus dirancang secara khusus. Selama ini, metode fraksinasi minyak kelapa merujuk pada data dan teknik fraksinasi minyak sawit, minyak kedelai, atau minyak komersial lainnya yang jelas memiliki karakteristik berbeda. Oleh karena itu, metode pendinginan khas dalam rangka fraksinasi minyak kelapa harus didefinisikan. Hasil penelitian ini menunjukkan bahwa ada tiga fase pendinginan penting yang berbeda untuk proses kristalisasi minyak kelapa, yaitu fase pendinginan awal, pendinginan kritis dan kristalisasi. Fase pendinginan awal adalah pendinginan dari suhu rejuvenasi minyak $\left(70^{\circ} \mathrm{C}\right)$ hingga suhu dimulainya proses kristalisasi. Untuk minyak kelapa, suhu dimulainya kristalisasi terjadi pada $29^{\circ} \mathrm{C}$ (ditetapkan berdasarkan data pengukuran kandungan lemak padat atau SFC). Fase pendinginan kritis adalah pendinginan dari suhu dimulainya proses kristalisasi minyak hingga suhu kristalisasi yang ditetapkan. Fase kristalisasi adalah pendinginan untuk menjaga suhu minyak konstan pada suhu kristalisasi yang telah ditentukan. Pada fase pertama, pendinginan dapat dilakukan dengan secepat-cepatnya guna menghemat waktu tetapi padafasekedua harus dilakukan dengan laju pendinginan kurang dari $0,176^{\circ} \mathrm{C} /$ menit untuk menghasilkan kristal yang stabil secara fisik dan mudah untuk difraksinasi. Penelitian ini telah berhasil memperoleh metode fraksinasi kering khas untuk minyak kelapa pada skala pilot plant $(120 \mathrm{~kg})$ dan telah menghasilkan prosedur pendinginan yang efektif untuk menghasilkan fraksi minyak dengan sifat fisiko-kimia seperti yang diharapkan. Kondisi dan persyaratan utama yang harus dikelola dan dipelihara pada fraksinasi kering minyak kelapa telah diidentifikasi dan diketahui, sehingga proses fraksinasi untuk tujuan tertentu telah mampu dirancang secara lebih praktis.
\end{abstract}

Kata kunci: fraksinasi, kristalisasi, laju pendinginan, minyak kelapa

${ }^{*}$ Corresponding Author:

E-mail: mursalin@unja.ac.id 


\section{INTRODUCTION}

Proper knowledge about fat fractionation kinetics is needed to produce end-product with the purposed characteristics, thus trial and error treatment is no longer required. Recently, the effect of temperature, cooling rate, and process duration on the behaviour of oil fractionation (especially coconut oil) and characteristics of fraction produced are not surely known. Hence, in phenomena occured due to the difference of factors applied can not be explained clearly and only small amount data for quantitatively kinetics are available (Timms, 2005, Chaleepa et al., 2010).

Fractionation is the physical method using crystallization properties from triacylglycerol (TAG) to separate mixture into liquid fraction with low melting point and solid fraction with high melting point (Ramli et al., 2008; Sarmidi et al., 2009). The concept of fractionation is based on the difference of TAG melting point (Huey et al., 2009). The successful of fractionation depends on the behaviour of TAG phase composition (Chen et al., 2007). The phase concept and behaviour do not depend only on TAG melting point or polimorphic characters, but also on involved TAG mixture that differed in solid and liquid states (Calliauw et al., 2010; Timms, 2005).

Dry fractionation of fat generally divided into two stages, crystallization to produce solid crystal in a liquid matrices and filtration to separate the crystal formed. According to Timms (2005), the changes occured in molecular level during fat crystallization are the forming of nucleous (nucleation), the growth of nucleous and the changes of behaviour phase (polymorphism, solid solutions). The overall changes in this molecular level are greatly affected by treatment in physical level as removal of heat. Therefore, cooling method (cooling temperature, decreasing temperature rate and the duration of cooling process applied) will determine the characteristics of fractionation yieldproduced.

Coconut oil contains very different fatty acid composition and TAG profile with other kind of fat or plant oil. This difference causes oil having boiling point and pattern of changing state from liquid to solid or vice versa, which is very distinct with other kind of oil. Therefore, crystallization behaviour and coconut oil fractionation is not able to be considered the same as other kind of oil. Coconut oil is in solid state at $70^{\circ} \mathrm{F}\left(21.1^{\circ} \mathrm{C}\right)$, but it will rapidly and perfectly melt at a slight below human body temperature (Gervajio, 2005; O’Brien, 2004).

\section{MATERIALS AND METHODS}

\section{Materials}

Main material used in this research was refined bleached deodorized coconut oil (RBDCNO) was obtained from PT. BARCO Jakarta, Indonesia.The other material wastriacylglycerol (TAG) standard from Sigma (St. Louis, MO USA).

\section{Dry fractionation method}

Dry fractionation applied in this research was the modification methods conducted by Zaliha et al. (2004) and Chaleepa et al. (2010), using oil crystallizator with capacity of $120 \mathrm{~kg}$, as ilustrated on Figure 1. Coconut oil, $120 \mathrm{~kg}$, which would be fractioned, was placed in oil crystallizator and heated at $70^{\circ} \mathrm{C}$ for 10 minutes. Then, the liquid oil being cooled with variation of cooling rate $(0.1-$ $0.9^{\circ} \mathrm{C} /$ minute) until it reached the crystallization temperature wanted $\left(18.0-22.5^{\circ} \mathrm{C}\right)$ and hold it in this temperature in a range of time (0-10 hours). During this crystallization process, it was stirred with the rate of $7.5 \mathrm{rpm}$. After that, semisolid and wet mass from the oil crystallized was separated into fraction of stearin and olein using vacuum filter.

\section{Stearin yield, medium chains triacylglycerol (MCT), and solid fat content (SFC)}

Determination of stearin yield, MCT and SFC were done by sampling.Sampling was taken six times at oil in crystallization rezim, which phase after critical cooling rezim where oil temperature was constantly maintained. Each sample (125-250 mL of cryztallized oil was taken from crystallizator tank) filtered using vacuum with Whatman No. 40 then each fraction (olein and stearin) was scaled and characterized. Stearin yield was calculated by comparing amount of stearin fraction to sample. MCT content for each fraction was determined based on the result of TAG composition analysis. The content of MCT determined by the accumulation of four-firstpeak in chromatogram of TAG as the results of TAG content analysis, which indicated as $\mathrm{Cp}-\mathrm{Ca}-\mathrm{La}$, CaCa-La, Ca-La-La, and La-La-La where Cp is Caprilic, $\mathrm{Ca}$ is Capric, and $\mathrm{La}$ is Lauric acid.TAG analysis were conducted by modification method of Byrdwell et al. (2001) using HPLC (Hewlett Packard series 1100, Germany). SFC for each fraction was determined using Nuclear Magnetic Resonance Analyser (Bruker Minispec PC 100, Germany). 


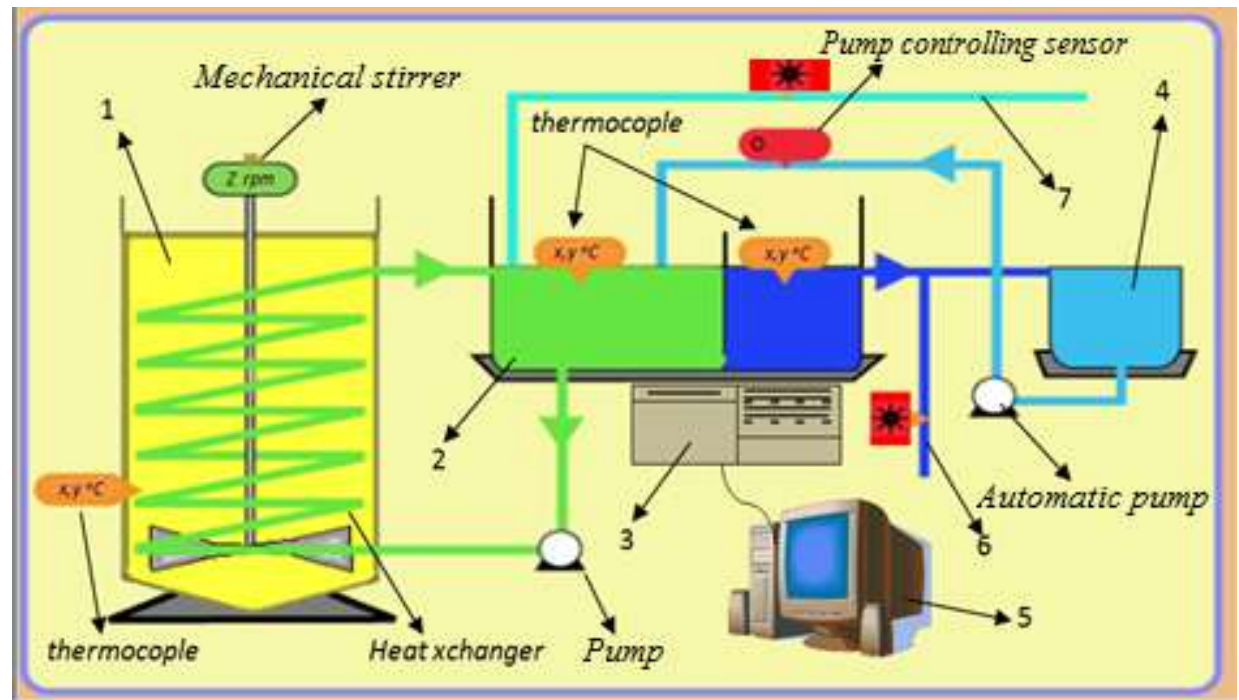

Figure 1. Crystallizator being used and its components; $1=$ crystalizator tank; $2=$ chamber filled with cooling water; $3=$ electronic circuit regulating cooling system; $4=$ chiller as cold water supplier; $5=$ computer to input program and recording the changes of oil and water; temperature; $6=$ outlet water from cooling chamber; $7=$ inlet water from reservoir as alternative cooler

\section{RESULTS AND DISCUSSION}

\section{Cooling curve of coconut oil during crystalliza- tion process}

This research has produced various forms of cooling curve that is the temperature change curves of coconut oil during crystallization. From the observation on cooling curves obtained, generally, typical curve of temperature change of coconut oil during crystallization is illustrated on Figure 2.

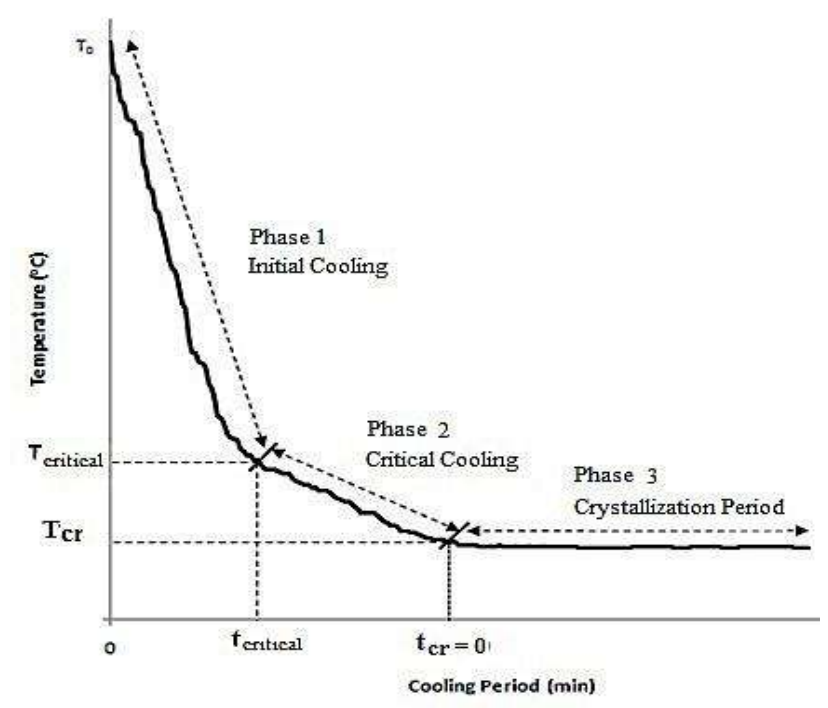

Figure 2. Typical temperature change curve of coconut oil during crystallization, $\mathrm{T}=$ temperature, $\mathrm{t}=$ time, $\quad \mathrm{cr}=$ crystallization (Mursalin et al., 2013a)
The identification result of coconut oil cooling curve during crystallization (Figure 2) showed that three stages (phases) of cooling that affected crystallization process and its fractionation. First phase was initial cooling, where cooling was started from initial oil temperature $\left(T_{0}\right)$ to initial crystallization temperature $\left(T_{\text {critical }}\right)$. In this research initial crystallization temperature for coconut oil (temperature where crystal nucleus started formed) was assumed occurred at $29^{\circ} \mathrm{C}$. It was supported by NMR analysis result indicated that at $29^{\circ} \mathrm{C}$ coconut oil start crystallized with solid fat content (SFC) in arange of $1.0-2.0 \%$ (data not presented).

Second phase (critical cooling) was cooling from $29^{\circ} \mathrm{C}$ to predetermined crystallization temperature. It was predicted that in this second cooling phase there was an increase in forming intensity of crystal nucleus (propagation) which occurred after first nucleus formed till reached the crystallization temperature $\left(T_{c r}\right)$. This paper will shows that cooling rate at the second phase highly affected TAG profile and MCT content of each oil fraction produced. Therefore, cooling rate in this phase is called critical cooling $\left(\mathrm{v}_{\mathrm{c}}\right)$.

Final phase was cooling process to maintain crystallization temperature constantly as it was set before. It was presumed at this cooling phase there was fusion of crystal nucleus to form larger crystal (crystal growth).

\section{Effect of critical cooling rate to each SFC fraction}

Through coconut oil fractionation olein fraction with lower SFC and stearin with higher SFC were produced (compared to oil prior to fractionation). 

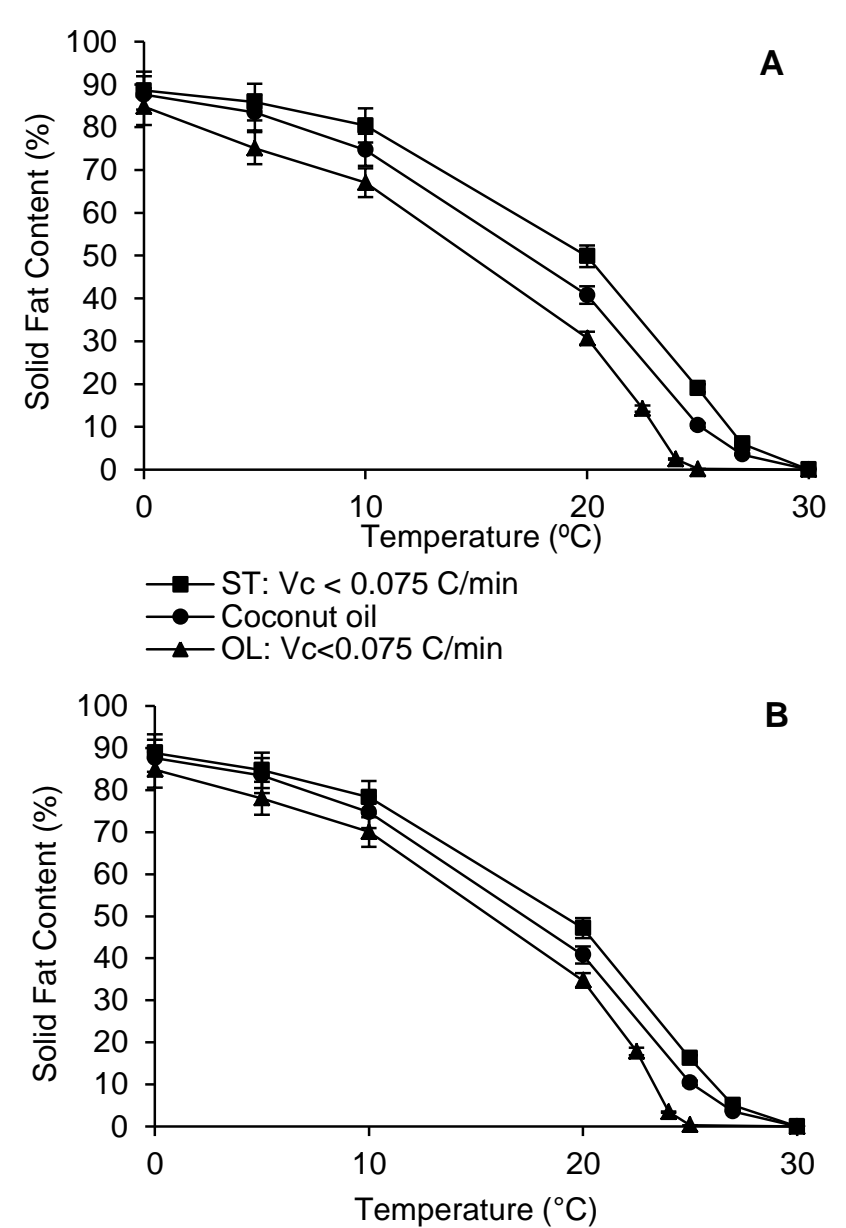

$\rightarrow$ ST: $0.075<\mathrm{Vc}_{0}<0.125 \mathrm{C} / \mathrm{min}$

$\rightarrow-$ Coconut oil

$\multimap$ OL: $0.075<\mathrm{Vc}_{\mathrm{c}}<0.125 \mathrm{C} / \mathrm{min}$

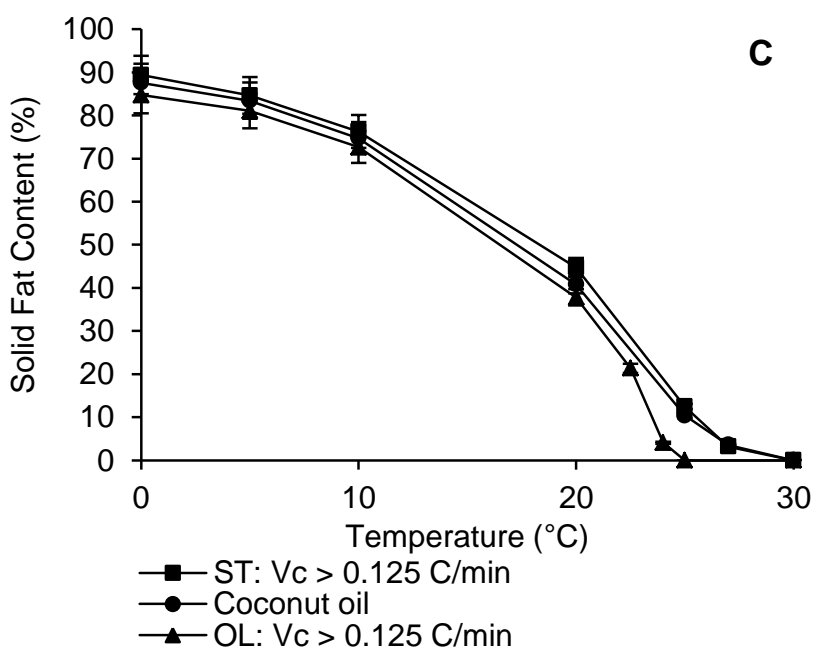

Figure 3. SFC profile of coconut oil at olein and stearin fraction before and after fractionation for critical cooling rate $\left({ }^{\circ} \mathrm{C} /\right.$ minute $)$ less than $0.075(\mathrm{~A})$, ranging from 0.075 0.125 (B) and higher than $0.125(\mathrm{C}) ; \mathrm{OL}=$ olein; $\mathrm{ST}=$ stearin; $\mathrm{v}_{\mathrm{c}}=$ critical cooling rate (Mursalin et al., 2013b)
Description of SCF olein and stearin fraction after coconut oil fractionation as the function of the critical cooling rate is depicted in Figure 3 . The decreasing of SFC value at olein fraction or its increasing at stearin fraction was not the same at each critical cooling rate (Figure 3 ). The highest increase of SFC value was appeared in stearin fraction with a lower rate of critical cooling $\left(\mathrm{v}_{\mathrm{c}}<\right.$ $0.075^{\circ} \mathrm{C} /$ menit). The higher the critical cooling rate, the lower the SFC changes both in olein and stearin fraction. It indicates that high critical cooling rate led to ineffectively separation of olein and stearin fraction due to imperfection of crystal form during crystallization process.

\section{Changing pattern of MCT content in coconut oil fraction during crystallization}

Solid and liquid state of coconut oil was extremely given by accumulation of molecule weight properties and melting point of its TAG composition. Different TAG compositions will produce different melting points of oil (Huey et al., 2009; O'Brien, 2004). One of prominent TAGs with a high economic value in coconut oil is MCT where the number of carbon chain about 8-12.

MCT content of coconut oil stearin fraction produced from all cooling treatments will decrease meanwhile MCT content of olein fraction will increase proportionally to the longer period of crystallization applied. Pattern changing of MCT content of coconut oil olein fraction during crystallization was less affected by initial cooling rate at first stage, but strongly affected by critical cooling rate at the second stage and duration of crystallization process at the third stage even though difference of crystallization temperature at the third stage also did not show significant effect.

Critical cooling rate had negative correlation with MCT content (MT, \%) that could be produced during crystallization process. In the range of critical cooling rate examined, lower critical cooling rate has produced higher MCT content, and vice versa (Figure 4A). Changes of MCT content during crystallization process at various critical cooling rates being examined were as follows: $M T=1.552 \ln (t)+$ 51.23 for $\mathrm{V}_{\mathrm{c}}<0.075^{\circ} \mathrm{C} / \mathrm{min}$; $\mathrm{MT}=1.997 \ln (\mathrm{t})+46.29$ for $0.075<\mathrm{v}_{\mathrm{c}}<0.125^{\circ} \mathrm{C} / \mathrm{min}$; and $\mathrm{MT}=2.072 \ln (\mathrm{t})+45.18$ for $v_{c}>0.125^{\circ} \mathrm{C} / \mathrm{min}$.

Increasing of MCT content number of coconut oil during crystallization period obviously was affectted by crystallization temperature $\left(\mathrm{T}_{\mathrm{cr}},{ }^{\circ} \mathrm{C}\right)$. Common effect of crystallization temperature and critical cooling rate on changes pattern of MCT content during crystallization, specifically for critical cooling rate less than $0.125^{\circ} \mathrm{C} /$ minute is illustrated on Figure 4B. From this figure, it can be concluded that a range of crystallization temperature of 21.30$21.73^{\circ} \mathrm{C}$ has produced MCT content during 
crystallization process higher than other temperature ranges both below or above it. Changes of MCT content during crystallization process at critical cooling rate less than $0.125^{\circ} \mathrm{C} /$ minute at each range of crystallization temperature were as follows: $M T=1.884 \ln (\mathrm{t})+49.59$ for $21.30<\mathrm{T}_{\mathrm{cr}}<21.73^{\circ} \mathrm{C}$ $M T=1.388 \ln (\mathrm{t})+51.04$ for $18.82<\mathrm{T}_{\mathrm{cr}}<18.91^{\circ} \mathrm{C}$; and $M T=1.710 \ln (\mathrm{t})+47.48$ for $21.90<\mathrm{T}_{\mathrm{cr}}<22.38^{\circ} \mathrm{C}$.

A

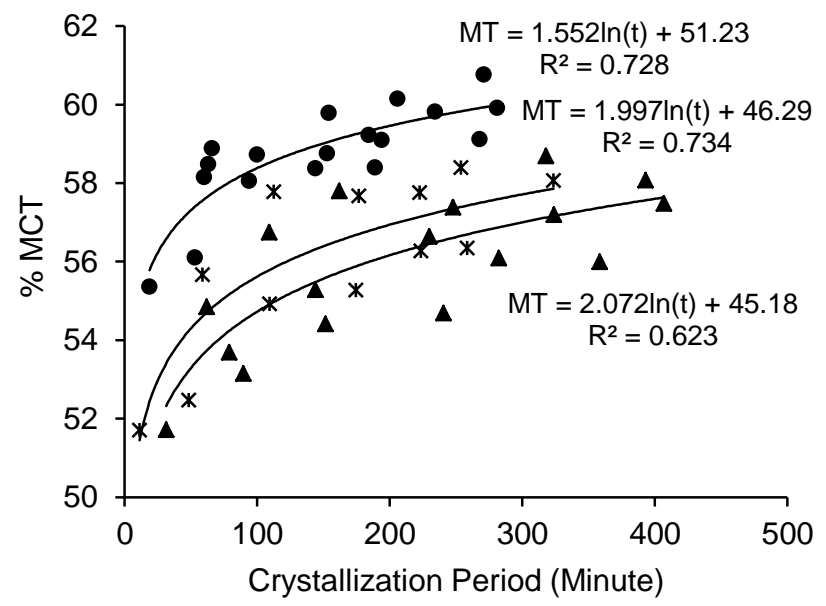

- Vc $<0.075 \mathrm{C} / \mathrm{min}$

$* 0.075<\mathrm{Vc}<0.125 \mathrm{C} / \mathrm{min}$

$\Delta \mathrm{Vc}>0.125 \mathrm{C} / \mathrm{min}$

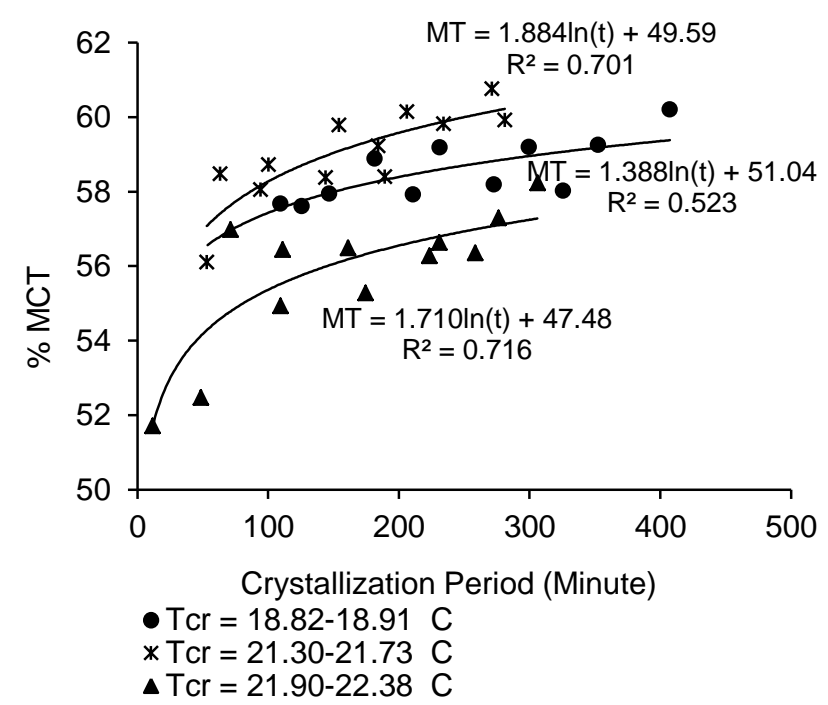

Figure 4. Relationship between crystallization period and changes pattern of MCT olein fraction of coconut oil at three group of critical cooling rate (a); and at critical cooling rate below $0.125^{\circ} \mathrm{C} /$ minute at three group of crystallization temperature (b). $v_{c}=$ critical cooling rate, $T_{c r}=$ crystallization temperature; MT $=\mathrm{MCT}$ content; $\mathrm{t}=$ crystallization period (Mursalin et al. 2013a)
Crystallization temperature at range of 21.30$21.73^{\circ} \mathrm{C}$ obviously produced higher MCT content than the content being produced outside the temperature range. It was reasonably understood because at low crystallization temperature, crystal size formed relatively smaller so that olein fraction contained much stearin fraction (mixed), while MCT was much at olein fraction. For high crystallization temperature, it is expected that crystallization was not intensively occurred so that there was still much of coconut oil part being not crystallized and considered as olein fraction; consequently MCT content measured was lower.

\section{Cooling procedure of coconut oil to produce high MCT content-oil}

Coconut oil fractionation produced olein fraction with higher MCT content $(59.98 \pm 0.79 \%)$ and stearin with lower MCT content $(48.75 \pm 0.67 \%)$, compared to oil before fractionation $(53.71 \pm 0.96 \%)$. Description of MCT changes of olein and stearin fraction after coconut oil fractionation as the effect of critical cooling rate and crystallization temperature is illustrated on Figure 5.

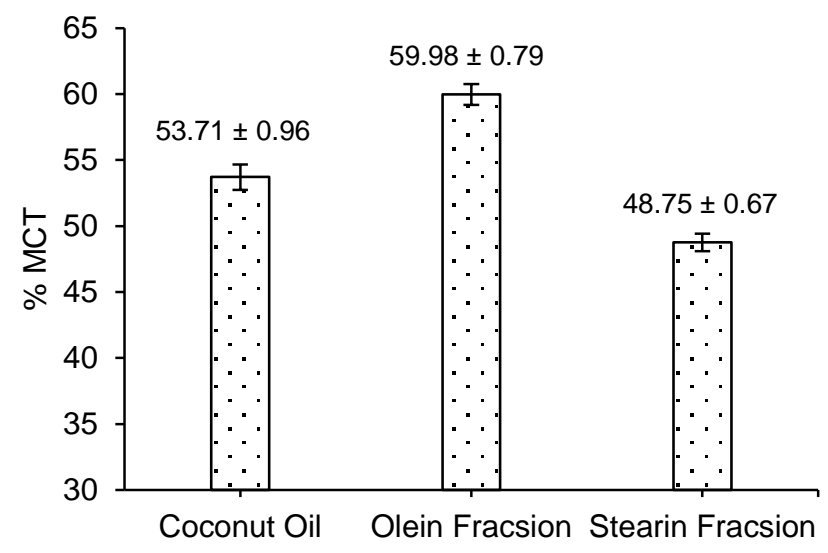

Figure 5. MCT profile of coconut oil for olein and stearin fraction before and after fractionation

Figure 5 illustrated MCT value of coconut oil before and after fractionation. Value presented for each stearin and olein fraction is an average value of MCT measurement at the end of the process from combination of all crystallization temperatures, critical cooling rate and crystallization period. Oil with high MCT content $(60 \%)$ could be obtained by arranging critical cooling rate $<0.125^{\circ} \mathrm{C} /$ minute at a range of crystallization temperature of 21.30$21.73^{\circ} \mathrm{C}$ for 250 minutes. 


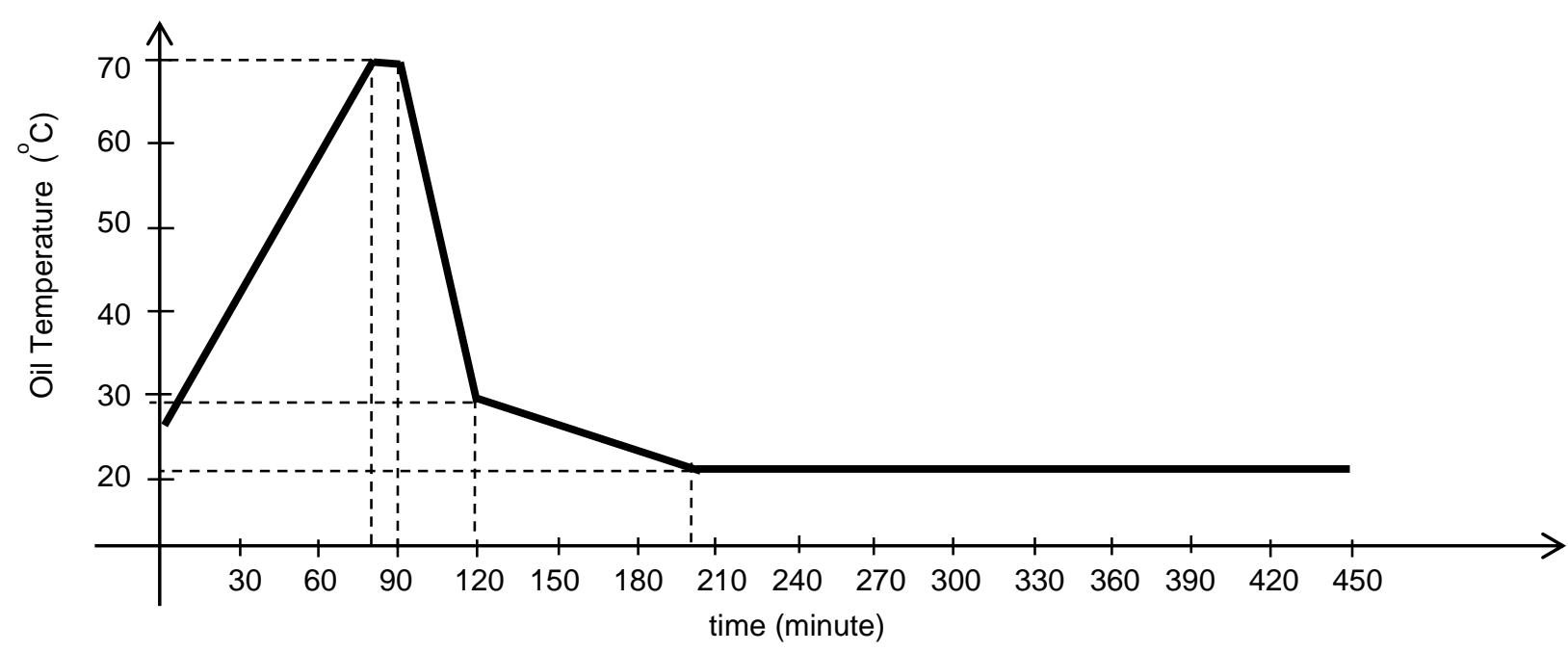

Figure 6. Scheme of effective cooling procedure to produce oil fraction (olein) with high MCT content

A cooling procedure to obtain oil fraction (olein) with high MCT content could be conducted for $7.5 \mathrm{~h}$ ; consisted of heating for rejuvenation of 90 minutes, initial cooling to reach temperature $29^{\circ} \mathrm{C}$ for 30 minutes with rate $1.5^{\circ} \mathrm{C} /$ minute, critical cooling to reach crystallization temperature $21^{\circ} \mathrm{C}$ for 80 minutes and crystallization process for 250 minutes. Schematically, this cooling procedure is illustrated on Figure 6.

\section{CONCLUSION}

This research has succeeded obtaining a specific dry fractionation method for coconut oil at pilot plant scale $(120 \mathrm{~kg})$. Conditions and essential requirements which have to be controlled and maintained in stages of dry fractionation of coconut oil have been identified and known, so that fractionation process for specific purposes could be practically designed. Three crucial stages of cooling in coconut oil dry fractionation were initial cooling, from the appropriate temperature to rejuvenate oil to $29^{\circ} \mathrm{C}$, from temperature at $29^{\circ} \mathrm{C}$ to crystallization temperature, and crystallization stage at constant cool temperature. At the first stage, it could be conducted by rapid cooling rate (to save time and energy) but at the second stage it must be conducted at cooling rate below $0.176^{\circ} \mathrm{C} /$ minute. Third stage had been set the period based on the objective of fractionation expected.

Oil with high MCT content $(60 \%)$ could be obtained from olein fraction by setting initial cooling rate maximally, critical cooling rate below $0.125^{\circ} \mathrm{C} /$ minute and crystallization temperature of $21.30-21.73^{\circ} \mathrm{C}$ with the crystallization period of 250 minutes. Cooling procedure could be conducted for 7.5 hours that can be divided into oil for 90 minutes rejuvenation, initial cooling to reach $29^{\circ} \mathrm{C}$ for 30 minutes with the rate of $1.5^{\circ} \mathrm{C} /$ minute, critical cooling to reach crystallization temperature $21^{\circ} \mathrm{C}$ for 80 minutes and crystallization process for 250 minutes.

\section{REFERENCES}

Byrdwell WC, WE Neff, GR List. 2001. Triacylglycerol analysis of potential margarine base stocks by high-performance liquid chromatography with atmospheric pressure chemical ionization mass spectrometry and flame ionization detection. J Agr Food Chem 49: 446-457. DOI: 10.1021/jf0008801.

Calliauw G, Fredrick E, Gibon V, De Greyt W, Wouters J, Foubert I, Dewettinck K. 2010. On the fractional crystallization of palm olein: solid solutions and eutectic solidification. Food Res Int 43: 972-981. DOI: 10.1016/j.foodres.2010. 01.002.

Chaleepa, K, Szepes A, Ulrich J. 2010. Effect of additives on isothermal crystallization kinetics and physical characteristics of coconut oil. Chem Physic Lip 163: 390-396. DOI: 10.1016/j. chemphyslip.2010.03.005.

Chen CW, Chong CL, Ghazali HM, Lai OM. 2007. Interpretation of triacylglycerol profiles of palm oil, palm kernel oil and their binary blends. Food Chem 100: 178-191. DOI: 10.1016/j.foodchem. 2005.09.044.

Gervajio GC. 2005. Fatty Acids and Derivatives from Coconut Oil, in Industrial and Nonedible Products from Oils and Fats. Bailey's Industrial Oil and Fat product, Sixth Edition, Volume $6^{\text {th }}$. Edited by F. Shahidi. 1-56. John Wiley \& Sons, Inc. 
Huey SM, Hock CC, Lin SW. 2009. Characterization of low saturation palm oil products after continuous enzymatic interesterification and dry fractionation. J Food Sci 74: E177-E183. DOI: 10.1111/j.1750-3841.2009.01122.x.

Mursalin, Hariyadi P, Purnomo EH, Andarwulan N, Fardiaz D. 2013a. Dry fractionation of coconut oil using $120 \mathrm{~kg}$-scale crystallizer to produce concentrated medium chain triglycerides. Ind Crops Res J (LITTRI) 19: 41-49.

Mursalin, Hariyadi $\mathrm{P}$, Purnomo $\mathrm{EH}$, Andarwulan N, Fardiaz D, 2013b. The effect of critical cooling rate, temperature and crystallization duration on composition and profile of triacylglicerol and melting properties of fractionation product of coconut oils. J Ilmu Pert Indonesia (JIPI) 18: 614.

O'Brien RD. 2004. Fats and Oils; Formulating and Processing for Applications. CRC Press LLC. Washington, DC. P 40-42.
Ramli MR, Siew WL, Cheah KY. 2008. Properties of high-oleic palm oils derived by fractional crystallization. J Food Sci 73: C140-C145. DOI: 10.1111/j.1750-3841.2007.00657.x.

Sarmidi MR, El Enshasy HA, Hamid MA. 2009. Oil palm: the rich mine for pharma, food and fuel industries. Am-Eur J Agric Environ Sci 5: 767776.

Timms RE. 2005. Fractional crystallisation - the fat modification process for $21^{\text {st }}$ century. European journal of lipid science and technology Eur $\mathrm{J}$ Lipid Sci Tech 107: 48-57. DOI: 10.1002/ejlt.20 0401075.

Zaliha O, Chong CL, Cheow CS, Norizzah AR, Kellens MJ. 2004. Crystallization properties of palm oil by dry fractionation. Food Chem 86: 245-250. DOI: 10.1016/j.foodchem.2003.09.03 2. 